Comparative Philosophy Volume 4, No. 1 (2013): 67-89

Open Access / ISSN 2151-6014

www.comparativephilosophy.org

\title{
A DAOIST MODEL FOR A KANTIAN CHURCH
}

\author{
STEPHEN R. PALMQUIST
}

\begin{abstract}
Although significant differences undoubtedly exist between Daoism and Kant's philosophy, the two systems also have some noteworthy similarities. After calling attention to a few such parallels and sketching the outlines of Kant's philosophy of religion, this article focuses on an often-neglected feature of the latter: the four guiding principles of what Kant calls an "invisible church" (universality, purity, freedom, and unchangeableness). Numerous passages from Lao Zi's classic text, Dao-De-Jing, seem to uphold these same principles, thus suggesting that they can also be interpreted as core features of a Daoist philosophy of life. A crucial difference, however, is that members of a Daoist church would focus on contentment, whereas Kantian churches modeled on Christianity (the religious tradition Kant favored) would strive for perfection. The article therefore concludes by considering what a synthesis might look like, if a Kantian church were to be based on a Daoist interpretation of these four fundamental principles.
\end{abstract}

Keywords: Kant, Lao Zi, church, Dao-De-Jing, Daoism, comparative philosophy

To know and yet (think) we do not know is the highest (attainment); not to know (and yet think) we do know is a disease. ${ }^{1}$

\section{KANT AND DAOISM: THE BASIS FOR COMPARISON}

Kant's philosophy could be compared and contrasted with Daoist philosophy from various angles: his epistemology, moral/political philosophy, aesthetics, and

PALMQUIST, STEPHEN R.: Professor, Department of Religion \& Philosophy, Hong Kong Baptist University, Hong Kong. Email: stevepq@hkbu.edu.hk

\footnotetext{
${ }^{1}$ Lao Zi 1891, chapter 71. I use Legge's classic translation of Dao-De-Jing (hereafter DDJ), as he was a western-trained scholar who spent much of his life immersing himself in the language and culture of China. But translations of Lao Zi can differ widely, as the ancient Chinese is often cryptic. Where other translators differ significantly from Legge, I shall note alternatives, citing the translator's name and publication year. I shall put aside scholarly questions concerning authorship, treating Lao $\mathrm{Zi}$ as the sole author; taking a stand on such issues would have no significant impact on the argument defended
} 
philosophy of religion all have certain affinities with a Daoist worldview, ${ }^{2}$ though some features seem to stand in direct conflict. In epistemology, for example, the two employ completely different terms, yet arguably achieve a similar effect. Whether "ultimate reality" goes by the name of "the thing in itself" or "the Dao", both insist it is and must remain an unknown "something" that we can only presuppose as underlying the various "objects" or "daos" that we can know or name in the process of constructing our human world.

Kant's moral and political philosophy, as traditionally understood (i.e., as a system of deontological ethics and liberal politics), seems to contrast markedly with Lao Zi's ideals. However, a serious question for those engaging in such cross-cultural comparisons is whether the Dao-De-Jing ever even attempts to construct a pure moral/political system, as Kant did. ${ }^{3}$ If it does not, if its goal is something other than the construction of an abstract philosophical system, then it remains an open question whether Kant's system is compatible with the wise practical counsel found in Lao Zi (and other Daoist authors). Consider, for example, Kant's well-known claim that a good will is the only thing in the world (or even outside the world) that is "good without qualification". "This may seem like a proud claim to know the good, as if it were a first premise grounding all the building blocks of Kant's moral system. But it is not. Quite to the contrary, Kant's appeal to an ultimate "good will" has the effect of making all other claimed goods relative to this unknowable absolute. Given that Kant elsewhere repeatedly reminds us that we cannot know the depths of another person's will, or for that matter even our own will (see e.g., Kant 2009, 51), his claim about the good will may be compatible with the basic Daoist claim that the actions and events we perceive as good and evil are actually relative to the great Dao.

Comparing Daoist and Kantian aesthetics would be even more challenging, since both positions tend to be expressed in cryptic terms. One point that stands as a common denominator is that both Kant and Lao $\mathrm{Zi}$ appeal regularly and respectfully to nature as the context for understanding mankind's role in the universe. Lao Zi's idea of nature, however, is derived from the term zi-ran (自然), which also means "naturalness" or "self-so-ness", and assumes that a wealth of insight can be gained from observing and learning from nature's ways. By contrast, Kant's Critique of the Power of Judgment develops a complex web of theories about the role of human judgment in our experiences of beauty, sublimity, and natural purposiveness. While some work has been done on assessing whether the similarities or differences are more significant on such matters (see e.g., Nelson 2011, and note 32, below), very

\footnotetext{
${ }^{2}$ Referring to "a Daoist worldview" does not imply there is only one. Rather, I intend this phrase to refer to any set of life-guiding fundamental beliefs that a person draws from Dao-De-Jing. I make no claim as to whether or not any other type of Daoist worldview (e.g., one based on the Zhuang-Zi) could serve as the basis for a similar project of constructing a Kantian religious community.

${ }^{3}$ Boaz 1997, 23 (see also 27-8) identifies Lao Zi as the "first known libertarian." Such claims to locate Western theories in $D D J$ typically do not go so far as to claim that Lao Zi offers a systematically justified rational system of moral or political theory.

${ }^{4}$ See Kant 1785 , the first sentence of the first section.
} 
little has been written on compatibilities or conflicts between Daoism and Kant's theory of religion. ${ }^{5}$

One reason for this lacuna may be that relatively few Kant-scholars take Kant's Religion within the Bounds of Bare Reason very seriously, aside from reading the first of its four "Pieces", for some insight into the nature of evil and its debilitating effect on our attempts to be moral. So there is little interest in such a project among Kantians. Most who take an interest in the second half of Religion, where Kant portrays an "ethical community" as a necessary condition for human beings to overcome the affects of radical evil, simply ignore the fact that, for Kant, the only way human beings can work toward the goal of constructing an ethical community is to organize themselves into groups called churches. ${ }^{7}$ A second reason for the almost total lack of comparison between Kantian religion and Daoism is that the latter term describes not only philosophical Daoism, but also the rich historical tradition emerging from it, the empirical religion (or "historical faith", as Kant would call it) bearing the same name; for many aspects of religious Daoism exhibit little or no similarity to the Christianity that Kant took as the standard model for an historical faith. ${ }^{8}$ In this article I shall avoid the complexities involved in assessing whether religious Daoists have ever actually conducted themselves in a manner consistent with what Kant calls "true religion". My goal, rather, will be to consider the more abstract question of whether a hypothetical community of philosophically-minded religious believers would be able to establish a "Kantian church" if they were to use as their guiding text not the Bible, with its emphasis on constant striving for perfection, but Lao Zi's Dao-De-Jing, ${ }^{9}$ where the importance of purposive action is downplayed in order to emphasize letting nature have its way.

The following sketch of a Daoist model for a Kantian church will proceed in three stages. First, I shall sketch in $\$ 2$ the essential features of Kant's philosophy of religion, paying special attention to the much-neglected four "principles" that Kant presents as the guiding thread for the "true" church. I shall then turn in $\S 3$ to the DaoDe-Jing in search of textual evidence that key features of Kant's theory of religion,

\footnotetext{
${ }^{5}$ What has been written tends to ignore the similarities and regard Daoist and Kantian philosophies as antithetical. See e.g., Mueller 2009, especially pp.79-88, and Wohlfart 2010.

${ }^{6}$ Kant's word, Stück, typically translated as "Book" or "Part", actually means "piece". As I noted in Palmquist 2009a, 18n, Kant appears to have chosen this term to call attention to the fact that he wrote the four parts of the book as a series of four "pieces" (i.e., journal articles) for publication in the Berliner Monatsschrift.

${ }^{7}$ Indeed, after Kant offers this crucial argument (§IV, Division One, Third Piece), he uses the word "church" almost exclusively, with only a handful of subsequent references to the "ethical community". Yet most commentators write as if Kant uses only the latter term.

${ }^{8}$ In addition to (and sometimes quite distinct from) religious Daoism, Daoist philosophy has given rise to certain quasi-religious (meditative) practices, such as Tai-Ji and Qi-Gong. While these would surely be relevant to a more detailed analysis of how the project I outline here would actually be implemented, they still relate more to historical faith, which Kant regards as the "clothing" of empirical religion, rather than to the moral faith that lies at its core. As such, they are outside the scope of the present study.

${ }^{9}$ Anyone who regards this suggestion as untenable from the start should consider that the Dao-De-Jing is one of the most frequently translated books ever written, perhaps second only to the Bible.
} 
especially the four principles, can be found therein. After considering some possible objections to this whole project, $\S 4$ concludes by offering general reflections on what a Daoist Kantian church might actually look like, were it to be manifested in a human community.

\section{KANT'S FOUR PRINCIPLES OF CHURCH ORGANIZATION AS GUIDELINES FOR TRUE RELIGION}

Most of the fundamental principles of Kant's philosophical theology are well known, so a brief overview will suffice. First, in his Critique of Pure Reason (1781) Kant argues that knowledge arises only when concepts are synthesized with corresponding intuitions, and that because the concept of God describes a being who by definition cannot become an object of human intuition, theoretical knowledge of God is impossible. He explains that this need not be bad news for religious believers, for although we can never prove God's existence, neither can anti-religious persons prove God's non-existence. Religion must therefore remain a matter of faith, not knowledge.

Second, in his Critique of Practical Reason (1788), Kant argues that as free agents we are bound by a universal moral law that requires good persons not to appeal to any outside influence (such as happiness, or divine revelation) as the grounding for moral choices, yet this same law requires us to believe that those who obey it will somehow eventually attain happiness. In the world, filled as it is with persons who are subject to the inclinations that arise from our sensible (embodied) nature, we often see evil people who are happy and good people whose desires remain unfulfilled; Kant therefore insists that practical reason "needs" to postulate the existence of God and a future life, in order for us to be rationally justified in seeking to be morally good in this life. ${ }^{10}$

Third, in his Critique of Judgment (1790), Kant argues that our experiences of beauty, sublimity, and natural purposiveness exemplify how the realms of freedom and nature come together in order to justify our hope that the postulates of practical reason are more than just wishful thinking, but really exist in the world as we experience it. This moral teleology portrays belief in God in terms that we might today call "existentially necessary". ${ }^{11}$

One would be hard pressed to construct, solely based on these three aspects of Kant's philosophical theology, any actual religious organization. The God of Kant's three Critiques is, to this extent, the God of the philosophers. However, this situation changes in Religion, where Kant's philosophy of actual religion comes to the fore. Having defined religion as "the cognition of all our duties as divine commands" (e.g., Kant, 2009, 153), Kant distinguishes in the second Preface between two "experiments" conducted in the book: the first constructs a system of rational religion

\footnotetext{
${ }^{10}$ For a more detailed explanation of Kant's much-neglected notion of immortality, see Palmquist 2013.

${ }^{11}$ For a more detailed explanation and assessment of all three of these basic aspects of Kant's philosophical theology, see Palmquist 2000, Chapter IV and Appendix IV.
} 
based on principles of "bare" (i.e., unassisted, unclothed) reason; the second examines how far one can interpret the "clothing" provided in the scripture of a real, empirical religion as being consistent with and complementary to the religion required by moral reason. The second "experiment" (Versuch) makes an "attempt" (Versuch) to interpret the scripture of a specific religion so that its essential tenets are compatible with those of the rational system that was brought to light by the first experiment (12). Kant gleans his data for the second experiment from the Bible, but frequently implies that this experiment could be conducted by using material from other religious traditions ${ }^{12}$ - later adding that success is most likely for traditions based on a sacred text. ${ }^{13}$

Kant argues in the First Piece that the presence of evil in the world requires us to assume a fundamental bent toward evil in the entire race, ${ }^{14}$ one that requires an appeal, as he elaborates in the Second Piece, to some form of divine assistance at the individual level. In the Third Piece he further argues that the human race has a special duty to form itself into a "community", based on moral laws. (He distinguishes between ethical and political communities: whereas politics utilizes and depends on external force to insure compliance with laws, ethics can be legislated only "internally". ${ }^{15}$ ) To conceive even the possibility of an ethical community ever coming into being, Kant argues, we must regard it as "a People of God under moral laws". ${ }^{16}$ This, Kant goes on to clarify, means that the only way we can ever hope to fulfill the purpose of human nature is to band together into religious communities-otherwise known as "churches".

The "true religion" practiced by members of a Kantian church, however, consists of not just any churchly traditions. In its essential form it is an "invisible" ideal with four guiding principles that Kant lists in an order corresponding directly to that of the

\footnotetext{
${ }^{12}$ He initially describes the second experiment as starting "from some supposed revelation" (Kant 2009,12 ), and throughout the book he refers to a wide variety of other religious traditions.

${ }^{13}$ Kant states this most pointedly in the heading of $\S \mathrm{V}$ (Division One, Third Piece), which comes immediately after the section that lists the four basic principles constituting a true church: "The Constitution of Any Church Always Starts from Some Historical (Revelation) Faith... and This Is Best Founded on a Holy Scripture" (Kant 2009, 102); §V then examines various advantages (and dangers) arising from the tendency to depend on a text (102-9). Green (1978) effectively illustrates how Kant's second experiment can be applied just as effectively to religions other than Christianity, focusing on Judaism, Hinduism, and Confucianism. But little attention has been given in this respect to Daoism. My goal here is therefore to assess, adopting an approach similar to Green's, how comfortable a "fit" there may be between Kant's system of religion and Lao Zi's Dao-De-Jing. The fact that I am focusing on Daoism here does not imply that a similar project could not be attempted for other Chinese traditions. Indeed, what Green did for Confucianism could also be done for Buddhism, with its distinct emphasis on how morality requires us to transcend the illusions of the phenomenal world (manifested primarily as suffering).

${ }^{14}$ For an analysis of the structure of Kant's argument here, see Palmquist 2008.

${ }^{15}$ Kant 2009, 98-100. Lao $\mathrm{Zi}$ introduces a similar distinction in $D D J 30$, where he claims the Daoist leader will not control the kingdom through conventional (political) methods: "He who would assist a lord of men in harmony with the Tao will not assert his mastery in the kingdom by force of arms. Such a course is sure to meet with its proper return."

${ }^{16}$ Kant 2009, 98. For an analysis of the structure of Kant's argument here, see Palmquist $2009 \mathrm{~b}$.
} 
four "categories" introduced in the first Critique: quantity, quality, relation, and modality. ${ }^{17}$ All other characteristics of a Kantian church (i.e., anything relating to external matters, such as the historically-conditioned beliefs of its members or the rituals or other conventions that may dictate how members interrelate) are optional extras, except insofar as they conform to and thereby reinforce these basic guidelines. He lays out these principles so concisely that we may simply quote the relevant passage. The true church, he says (Kant 2009, 101-2), can be recognized by:

1.Its universality and consequently numerical unity, the predisposition for which it must contain within itself: namely that, even though divided into contingent opinions and at variance, yet with regard to the essential aim it is built on such principles as must lead it necessarily to the universal union into a single church (hence no denominational schism).

2.Its character (quality); i.e., purity: union under no incentives other than moral ones (cleansed of the imbecility of superstition and the madness of fanaticism).

3. Its relation under the principle of freedom, the internal relation of its members among one another as well as the external relation of the church to the political power, both in a free state (hence neither a hierarchy nor an illuminatism, a kind of democracy by special inspirations that may differ from those of other persons according to the mind of each). 4.Its modality, unchangeability according to its constitution-yet with the exemption of the contingent arrangements, to be altered according to time and circumstances, which concern merely the church's administration - for which it surely must also contain the secure principles within itself (in the idea of its purpose) already a priori (hence under original laws, once publicly made precept[s] as if through a book of laws; not under chosen symbols, which, because they lack authenticity, are contingent, exposed to contradiction, and changeable).

As used here, the term "Kantian church" therefore refers to any group of goodhearted persons who eschew the use of political force and replace it with some set of religious beliefs and/or rituals that can empower the members of their organization to realize the basic principles of universality, purity, freedom, and unchangeability. What Kant-scholars rarely recognized is that, following this mid-point in the book's argument, Kant devotes the remainder of Religion to a detailed account of what it means to implement these principles. Rather than explain each main point of his argument, most of which focuses on the Christian tradition (the tradition Kant selected for his version of his second experiment), it will suffice for our purposes to describe one of the over-arching features Kant consistently assumes, yet never actually defends. Because membership of the true (invisible) church is determined by the genuineness of one's commitment to goodness, and because human beings cannot see into the depths of the human heart (see e.g., Kant 2009, 20)—so God alone can know who does and does not belong to the true church-we must make such assessments based on empirical evidence: human deeds.

\footnotetext{
${ }^{17}$ See Critique of Pure Reason A70/B95-A83/B109. It is no accident that Kant conforms his basic church principles to his list of categories, for as I have argued in Palmquist 2011, the categories are the basis for the architectonic form that guarantees the unity of all aspects of Kant's philosophical system.
} 
For this reason Kant repeatedly claims that, in order to provide themselves and others with evidence of their membership in the true church, good-hearted persons must continually strive to attain moral perfection. Kant makes such claims in countless passages, so a few examples will suffice. In the General Comment to the First Piece Kant argues that, because "human beings...can assess themselves and the strength of their maxims only by the upper hand that they gain over sensibility in time" (Kant 2009, 48), the change of heart that looks like a sudden revolution from God's perspective can be viewed from our human perspective "only as an evercontinuing striving toward the better, hence as a gradual reform of the propensity to evil, i.e., of the perverted way of thinking." Early in the Second Piece, Kant notes that "the ability of reason to become, through the mere idea of a law, master over all incentives striving against it is absolutely inexplicable" (59n)-thus implying that the reason we must constantly strive to improve is that our natural inclinations themselves strive to defeat the purposes of reason. Toward the middle of the Third Piece he adds that "although human beings might have attempted many forms of a church with unhappy result, they nonetheless ought not to cease striving after this purpose, if need be through new attempts that avoid as much as possible the mistakes of the previous ones" (105), "because this task...is for them simultaneously a duty". ${ }^{18}$ And in the Fourth Piece Kant distills his position into a basic principle, expressed in a variety of ways for different contexts of church government, such as: "virtue striving toward holiness" is "the true object" of all "church faith", so that "the sacred history" of a church tradition "must always be taught and explained as aiming at morality". 19

With this view of the Kantian church in mind, my goal in what follows is to conduct an alternative version of Kant's second experiment, selecting Daoism instead of Christianity as the historical tradition being tested. As mentioned in $\S 1$, I shall limit this initial investigation into the possibility of a Daoist-Kantian synthesis to the work ascribed to Lao Zi, Dao-De-Jing. In the next section I shall demonstrate that Lao Zi's text presents ample support for Kant's four principles, but without attempting to compare the details of how Lao Zi thought we should put them into practice with Kant's method of implementing them. This will prepare us to examine in $\S 4$ a crucial

\footnotetext{
${ }^{18}$ Kant's main argument regarding this unique duty "of humankind toward itself" comes in Kant 2009, 97-98 (see note 16, above). That Kant was aware of the limitations of this view of human striving is indicated by his reference, later in the Third Piece, to a "noteworthy antinomy" that arises whenever someone has "saving faith" (116-8): viewed theoretically, such faith requires an appeal to something beyond our own efforts, since we can never be perfect; yet viewed practically, our worthiness to receive such help "must be the effect of our own work and not again another's influence, where we are passive" (118). Kant thinks the antinomy can be resolved only if we make our belief in the latter the condition for our belief in the former, not vice versa (120): "One must with all one's powers strive after the holy conviction [Gesinnung] of a way of life pleasing to God, in order to be able to have faith that God's love for humankind (already assured to us through reason), insofar as humankind strives after his will with all its ability, will in some way compensate for the lack of the deed, in consideration of the sincere conviction."

${ }^{19}$ Kant 2009, 132. Kant succinctly expresses the same principle in the General Comment to the Fourth Piece: we can control nothing regarding God or our own ultimate fate that is "over and above the constant striving toward the good way of life" (191). In $\S 4$, below, I shall propose a synthesis whereby Kant emphasizes what we can control, while Daoism emphasizes what we cannot control.
} 
difference between these two ways of implementing Kant's four principles, with a view toward determining how a Daoist-Kantian church might actually operate.

\section{ARE KANT'S FOUR CHURCH PRINCIPLES AFFIRMED IN THE DAO-DE-JING?}

The overview of selected passages from Lao Zi's Dao-De-Jing, presented in the following four subsections, is not an attempt at scholarly exegesis of the text's "true meaning". While a careful philological analysis of ancient texts such as this one is undoubtedly worthwhile and valid in its own right, a focus on exegesis would inevitably distract us from the task at hand, which (in the spirit of Kant's own explicit approach to hermeneutics) has an unabashedly eisegetical aim. Just two subsections after introducing the four principles of the true church, Kant argues that the proper philosophical approach to interpreting classical (religious) texts is to read a moral meaning into them, even though the resulting interpretation "may often seem forced, and may often actually be forced" (Kant 2009, 110). He clarifies that this practical principle, which I call moral eisegesis, need not conflict with the biblical theologian's good and proper focus on the theoretical task of exegesis-i.e., discerning the author's original intent through historical and philological scholarship. Just as Kant presents moral interpretations of the Bible without pausing to consider what the texts he quotes might be taken to mean, from the point of view of biblical scholarship, and explicitly hopes that representatives of the two standpoints (of philosophical theologians and of biblical theologians) will work together toward a common goal (811), so also I shall present moral interpretations of the Dao-De-Jing without interacting with the vast body of scholarly analysis whose aim (at least in some cases) is to reach on objectively valid understanding of what Lao $\mathrm{Zi}$ actually intended to say.

With this clarification fully in view, my procedure in what follows will be to scan the text for initial evidence that it affirms ideas approximating Kant's principles of church organization. Again, I make no claim that Lao Zi himself saw these ideas as principles, nor that the text recommends setting up a religious community on the basis of its teaching. Rather, my question is only whether a group of good-hearted people who, having been convinced that setting up a Kantian church is a viable project, would be able to select Dao-De-Jing as the scriptural grounding for their community without being forced to reject Kant's basic principles outright. My hope (like Kant's, with respect to the biblical theologians of his day) is that this bold, insight-oriented approach will challenge any Lao $\mathrm{Zi}$ scholar who believes my eisegesis directly contradicts the text's intended meaning to come forward and provide evidence, based on historical and/or philological research, that the text cannot mean what I shall claim it can mean. In the absence of such counter-evidence at this stage, the following four subsections should adequately prepare us to consider (in $\S 4$ ) how such a real religious community might implement Lao Zi's version of Kant's principles, and to assess whether that implementation can still legitimately be called "Kantian". 


\section{A. Universality}

Kant's principle of universality requires that, no matter how many different opinions may exist on issues of less than ultimate importance, church members must regard their organization as being all-inclusive: the one true "invisible" church can encompass specific visible churches that exhibit widely divergent beliefs and rituals, provided they all seek to uphold the four basic guiding principles. ${ }^{20}$ Lao $\mathrm{Zi}$ hints at this first principle in Chapter 2 ("All in the world know the beauty of the beautiful") but appeals more directly to universality in Chapter 10: "(The Tao) produces (all things) and nourishes them; it produces them and does not claim them as its own; it does all, and yet does not boast of it; it presides over all, and yet does not control them. This is what is called 'The mysterious Quality' (of the Tao)." Chapter 51 reiterates: "the Tao produces (all things)", yet "makes no claim to the possession of them."

Just as Kant associates universality with the "invisible" underpinning of a church's empirical ("visible") manifestation, Lao $\mathrm{Zi}$ claims that the mysteriously indescribable features of the Dao are all grounded in "the One" (DDJ 14). Because "the sage holds in his embrace the one thing", he "manifests it to all the world" (DDJ $22)$; this awareness of the ultimate unity of all things is the source of Daoist freedom (see $\S 4$ ). Indeed, the term "Dao" often seems to be used synonymously with "the One" (e.g., DDJ 39), though Chapter 42 suggests a hierarchy: "The Tao produced One; One produced Two; ...". Although Lao Zi does not (and arguably, cannot) say much about this most basic principle of a Daoist-Kantian church, he does clarify that all persons (not just sages) have access to and are grounded in the Dao (whether they know it or not): "Even men who are not good are not abandoned by it" (DDJ 62). Just as the Kantian religious person must be willing to join together with anyone to participate jointly in the ethical community, even though each individual continues to struggle with radical evil, Lao Zi presents all human beings as ultimately united through their mysterious participation in the Dao, even though we often fail to recognize our oneness.

The fact that Lao $\mathrm{Zi}$ focuses on how "the sage" should act might be interpreted as counter-evidence to the claim that the Dao-De-Jing upholds the principle of universality. But this would be a misreading, for Lao $\mathrm{Zi}$ is not encouraging an elitist attitude, but attacking precisely that tendency—so prevalent among the Confucians of his day. A true Daoist "sage" recognizes that none of us are sages. Those who think they understand the Dao, and therefore go around telling everyone else about it, do not actually understand it. The fact that some people do not understand the Dao does not detract from the fact that those who do understand it recognize that it encompasses all, even those who do not understand.

\footnotetext{
${ }^{20}$ For a helpful discussion of the implications of Kant's theory of religion for the problem of religious pluralism, see Love 2010.
} 
B.

Kant's principle of purity requires church activities to be organized for the sole purpose of enhancing members' reliance on what is ultimate-i.e., the absolute good will. In particular, superstitious beliefs and fanatical rituals that provide merely the appearance of obeying God's commands (and are therefore often presumed to effect a quasi-magical transformation of a bad person into a good person) should be avoided. Dao-De-Jing alludes to the purity of the ultimate as early as Chapter 4: "How pure and still the Tao is, as if it would ever so continue!" ${ }^{21}$ Chapter 5 follows by claiming of both "heaven and earth" and "the sages" that they "do not act from (any wish to be) benevolent; they deal with the people as the dogs of grass are dealt with." 22 The dogs of the grass (or "straw dogs" [see note 22]) are considered to be irrelevant to what really matters; so Lao Zi appears to be saying we should not base our actions on what is not ultimate (e.g., on what other people may think is right or wrong). Instead, we should treat people as nature treats animals (and as animals treat grass), even though such purity of will might appear as a lack of concern for others. Perhaps this is why "The Tao is (like) the emptiness of a vessel" (DDJ 4): its purity is maintained as long as we resist filling it with anything but the Dao. Appealing to a similar logic, Lao Zi elsewhere observes that the empty space (i.e., their pure form, rather than the material

\footnotetext{
${ }^{21}$ The Chinese here is notoriously obscure. Among the many possible meanings of the five characters are: deep/clear/profound/tranquil (湛), oh!/ah!/so! (兮), like/seeming/surpassing (似), perhaps/ uncertain/else (或), and keeping/living/preserving/existing (存). This passage has therefore been translated in a wide variety of ways, including: "Darkly visible, it only seems as if it were there" (Lau 1963); "Deep and still, it appears to exist forever" (Chan 1963); "Submerged it lies, seeming barely to subsist" (Mair 1990); "Its depth is so deep, oh, that it seems somehow to exist" (Lynn 1999); "Is like the darkness of the deep; There its living presence bides" (Roberts 2001); and "Deep and clear! It seems to be there" (Ivanhoe 2001). Such variety need not detract from the relevance of this passage to Kant's second principle, however, once we recognize that his word for purity ("Lauterkeit") refers to a deep sense of honesty or sincerity, ultimately grounded in the good will-a reality that human beings seem to experience in our phenomenal lives, yet whose depths render it elusive to our grasp. When it comes to moral purity, "we see through a glass, darkly", as St. Paul wrote (1 Cor. 13:12, KJV). Recalling Paul Tillich's Ground of Being (the ultimate reality that cannot be said to "exist", since it is existence), I would translate the Chinese as: "So pure, its very existence seems uncertain!" This expresses essentially the same point made by Kant's second principle: what is ultimate remains pure even though (and perhaps precisely because) it remains beyond our grasp.

${ }^{22}$ Lau 1963 translates these lines to mean that sages (like heaven and earth) seem "ruthless" ““不仁” literally means "not benevolent”), treating people "as straw dogs" (“為媰狗” can also mean "as livestock"). Not surprisingly, this chapter is one of several typically cited as examples of Lao Zi's opposition to Confucian morality (see also chs. 18, 19, and 38): the Daoist sage treats other people more as a natural form of nourishment than as objects of principled "respect". While this seems to conflict with Kant's emphasis on respect for persons, this alternative translation conveys essentially the same point as the one made in Legge's: given that nature is an expression of the ultimate, the Daoist does not take what is non-ultimate (e.g., pretended respect for others) as a principle for action, but retains a pure focus on the ultimacy of the Dao, even if this results in actions others find objectionable. Kant never says that the person of good will is going to be well liked. Indeed, if you were hiding in Kant's house when your would-be murderer came to the door, you might describe Kant's refusal to lie as ruthless!
} 
they are made from) is what makes axels, vessels, doors, and windows so useful (DDJ 9,11).

When genuine moral purity fails to be honored as a guiding principle in any community, the ironic result is that concern for ethical "goodness" grows stronger. Thus, Chapter 18 laments: "When the Great Tao...ceased to be observed, benevolence and righteousness came into vogue. (Then) appeared wisdom and shrewdness, and there ensued great hypocrisy." This is what Kant calls "pseudoservice": when people forget the simple, pure truth (that we can have a good will even if we are not certain what is good, or as Lao $\mathrm{Zi}$ puts it, that the Way can be followed even though it remains unknown), they invent false "ways" that appear good but actually result only in muddying the water with "artful contrivances" that are best "abandoned" (DDJ 19). When Lao $\mathrm{Zi}$ says that leaders of the ideal community are to "renounce our benevolence and discard our righteousness" (DDJ 19 ), he does not mean we should abandon the purity of the Dao; rather, he means we must give up the wrong-headed, proud-hearted presumption that we know and can therefore tell others exactly what actions properly reflect the Dao of genuine benevolence and righteousness. These virtues are, as Kant would put it, noumenal; we can be aware of them and act upon them, but we cannot construct theoretical knowledge on their basis.

Lao Zi sometimes illustrates Daoist purity by comparing it to water. As we read in DDJ 8:

The highest excellence is like (that of) water. The excellence of water appears in its benefiting all things, and in its occupying, without striving (to the contrary), the low place which all men dislike. Hence (its way) is near to (that of) the Tao.

This "low place", arguably, is the "place" of unknowing; we human beings do not like to admit our ignorance, yet doing so (especially in moral matters) is the key to genuine purity. Thus, $D D J 78$ tells us:

There is nothing in the world more soft and weak than water, and yet for attacking things that are firm and strong there is nothing that can take precedence of it; - for there is nothing (so effectual) for which it can be changed.

... Words that are strictly true seem to be paradoxical.

After a stanza expressing disdain for scholars' tendency to think their past work is great, Chapter 45 concludes by associating the opposite virtue with purity: "Constant action overcomes cold; being still overcomes heat. Purity and stillness give the correct law to all under heaven." In other words, members of a Daoist-Kantian church would not strive to distinguish themselves from others by seeking out virtues such as benevolence, righteousness, etc.; they would follow nature's principle of opposites by moving when cold and remaining still when hot. "Because [the sage] does not strive, no one finds it possible to strive with him" (DDJ 66).

The opposite of such purity, as Chapter 46 explains, is selfish ambition and discontentment. The sage (DDJ 48) "diminishes [his doing] and again diminishes it, 
till he arrives at doing nothing (on purpose). Having arrived at this point of nonaction, there is nothing which he does not do." Daoists, therefore, are to focus on acting with moral purity just as much as Kantians do; the difference lies in the strategy each employs to encourage people to reach the desired goal. While Kant assumes reason can assist us in distinguishing good actions from evil ones, Lao $\mathrm{Zi}$ employs paradox to reconcile opposites - e.g., by portraying the easy as difficult and the difficult as easy ( $D D J 63)$ : "Therefore the sage, while he never does what is great, is able on that account to accomplish the greatest things." We shall examine the implications of this crucial difference between Kantian and Daoist understandings of purity in $\S 4$.

\section{Freedom}

The third guiding principle for the Kantian church, freedom, focuses on proper governance, and this too is one of Lao Zi's key themes, not only for the kingdom and its individual states, but for the neighborhood, the family, and the individual (DDJ 54). Kantian church leaders "rule" by insuring that members remain free from external constraints, so they can be guided internally by the moral law. The same would be true for a church based on Daoist principles. Of the wise sages of old Lao Zi says, in a cryptic passage that has been translated in various ways (DDJ 15): ${ }^{23}$

Who can (make) the muddy water (clear)? Let it be still, and it will gradually become clear. Who can secure the condition of rest? Let movement go on, and the condition of rest will gradually arise. They who preserve this method of the Tao do not wish to be full (of themselves). It is through their not being full of themselves that they can afford to seem worn and not appear new and complete.

Wise leaders remain pure by freeing their subjects to remain as they are: those who are still are free to remain still; those who move are free to keep moving. This is possible only when leaders are not "full of themselves". Leaders of a hypothetical Daoist-Kantian church would abhor "a boastful display" more than anything else (DDJ 53). For boasting contradicts the fundamental epistemological and moral presuppositions shared by Kantian and Daoist philosophy: we do not know the noumenal reality (the "Dao") that guides us, yet somehow we ought to conform ourselves it. This recognition of ignorance frees us from an over-dependence on the details of our historical religious context ( $D D J 56)$ : "He who knows (the Tao) does

\footnotetext{
${ }^{23}$ For example, Lau has: "Who can be muddy and yet, settling, slowly become limpid? / Who can be at rest and yet, stirring, slowly come to life? / He who holds fast to this way / Desires not to be full. / It is because he is not full / That he can be worn and yet newly made." Ivanhoe 2001 has: "Who can, through stillness, gradually make muddied water clear? / Who can, through movement, gradually stir to life what has long been still? / Those who preserve this Way do not desire fullness. / And because they are not full, then have no need for renewal." While the metaphors and precise details differ between these (and other) translations, the overall moral meaning seems to remain constant. Or, at least, I cannot see how such alternative translations (here and elsewhere) could be used to argue that Lao $\mathrm{Zi}$ is rejecting Kant's four principles, rather than endorsing them. I remain willing to be convinced, however, should a philologist see fit to argue otherwise.
} 
not (care to) speak (about it); he who is (ever ready to) speak about it does not know it." That is, the Daoist recognizes and practices Kant's insight, that the church's empirical forms must always be able to cease, otherwise we remain bound to something less than ultimate. ${ }^{24}$

An aspect of freedom implied but not explicated to any significant degree in Religion comes to the fore in Lao $\mathrm{Zi}$ (DDJ 22): the sage "is free from self-display, and therefore he shines... It is because he is thus free from striving that therefore no one in the world is able to strive with him." The freedom enjoyed by members of the Daoist-Kantian church would not only be between members and leaders and between the church and the state, but also between the individual person and his or her inclinations. Although Kant does not mention this latter form of freedom in his account of the third principle of church government, it is clearly consistent with (and implied by) his theory of the "change of heart" that human beings must experience in order to overcome radical evil. ${ }^{25}$

We read in Chapter 32 that relying on the named Dao, though derivative and nonultimate, can also promote freedom: "When they know to rest in it, they can be free from all risk of failure and error." Chapter 57 likewise applies this to the wider community: "A state may be ruled by (measures of) correction; weapons of war may be used with crafty dexterity; (but) the kingdom is made one's own (only) by freedom from action and purpose." Daoist freedom, therefore, is grounded on "the action of nonaction": ${ }^{26}$ the great state envelops small states by "condescending" to a low position, adopting a posture of "stillness" that Lao Zi compares to a female's way of overcoming a male (DDJ61): "The great state only wishes to unite men together and nourish them; a small state only wishes to be received by, and to serve, the other. Each gets what it desires, but the great state must learn to abase itself."27

That this freedom of nonaction has definite implications for the two aspects of freedom that Kant emphasizes (i.e., freedom between church members, and between church and state) is clarified in DDJ 58:

The government that seems the most unwise,

Oft goodness to the people best supplies;

That which is meddling, touching everything,

Will work but ill, and disappointment bring.

\footnotetext{
${ }^{24}$ Kant clarifies his position on the contingent role of the empirical church in a sentence appended to a footnote in the second edition (Kant 2009, 135n): "Not that it [i.e., "church faith" as grounded in "a holy book"] will cease (for it may perhaps always be useful and needed as a vehicle), but that it can cease; this is only to point to the intrinsic stability of the pure moral faith."

${ }^{25}$ Kant 2009, 47; see also 70, 76, and Palmquist 2010b. Kant's name for virtue, were it possible to free ourselves from the desire to do otherwise, is "holiness".

${ }^{26}$ The point of this central Daoist notion of wu-wei (無為; literally, "nothing done") is not that the sage just sits around doing nothing. Rather, the Daoist sage transcends the distinction between "doing" and "not doing" by ridding himself/herself of the pretentiousness that accompanies action done for a manifest purpose. For a thorough-going study of the concept, see Slingerland 2003, especially 77-118.

${ }^{27}$ See also Chapter 6, a chapter that Hansen 2004 begins with the title: "The Superiority of the Female".
} 
Political powers (whether leaders of church or state) are wisest when they give freedom to the people and the organizations they create. The chapter goes on to say that even correcting wrong should be resisted: "correction shall by a turn become distortion, and the good in it shall by a turn become evil." Here Lao Zi provides a recipe for ridding society of the self-deceiving effects of what Kant calls radical evil: if all our purposeful actions, especially those aimed at correcting other people's mistakes (by imposing our ethical self-understanding onto others), are by nature corrupted (taking us further from the Dao, from moral purity of heart), then the solution is to form social agreements based on freedom; in this context that means nonaction toward others. Lao Zi calls this "the mysterious excellence (of a governor)"; requiring leaders to resist the temptation to rule others by their own (presumed) "wisdom" (DDJ 65).

We find in these passages that Daoist freedom has a quality that is (or at least seems to be) quite distinct from Kantian freedom. According to Kant's moral philosophy, freedom means "autonomy": remaining separate from and undetermined by anything rooted in "nature", since the latter is the source of causal determination (the opposite of freedom). For Lao Zi, freedom means being "natural", submitting to and/or cooperating with the flow of how things are in the physical world, rather than being misled by artificial human constructions. As in their respective interpretations of purity, this difference seems crucial; but I shall argue in $\S 4$ that the Kant of Religion is closer to $\mathrm{Lao} \mathrm{Zi}$ on this point than first meets the eye.

\section{Unchangeableness}

Kant's final principle of church organization, unchangeableness, refers not to the way specific groups of people administer the organization they call their church (for this is merely contingent and can be different for different situations and cultures), but to the idea that the members of the church together agree that what is ultimate remains ultimate. Similarly, Lao Zi emphasizes the key to immutability in Chapter 7:

Heaven is long-enduring and earth continues long. The reason why heaven and earth are able to endure and continue thus long is because they do not live of, or for, themselves. This is how they are able to continue and endure.

The empirical administration of a Daoist-Kantian church might therefore be called "self-negating": ${ }^{28}$ a government's administrative rules are wise to the extent that their enforcers recognize their non-absolute status. Having founded a community, those who want it to reflect the formal principles of Kant's "true church" will insist that all rules are revisable except a very small set of genuinely universal principles, including the rule that all (other) rules are revisable. Church members may fine-tune their beliefs and rituals as much as they wish, but one does not meddle with the basic Constitution (i.e., the list of guiding principles Kant has formulated), because to do so

\footnotetext{
${ }^{28}$ Paul Tillich emphasizes this term in his political philosophy. For an in-depth discussion of its implications for the administration of religious organizations, see Chapter 4 of Palmquist 1993.
} 
would be to compromise its effectiveness (DDJ 9): "It is better to leave a vessel unfilled, than to attempt to carry it when it is full. If you keep feeling a point that has been sharpened, the point cannot long preserve its sharpness." The Dao-or the Kantian (unknowable) good will-is this point: religious organizations that continually define, refine, promote, and defend their articles of belief can avoid becoming dull and "pointless" only if the basic principles (being genuinely basic) are protected from such revision.

The sagely leader recognizes, according to Chapter 16, that the Dao is the only "regular, unchanging rule" one can use to govern a community:

To know that unchanging rule is to be intelligent; not to know it leads to wild movements and evil issues. The knowledge of that unchanging rule produces a (grand) capacity and forbearance, and that capacity and forbearance lead to a community (of feeling with all things). From this community of feeling comes a kingliness of character; and he who is king-like goes on to be heaven-like. In that likeness to heaven he possesses the Tao. Possessed of the Tao, he endures long; and to the end of his bodily life, is exempt from all danger of decay.

This should not be read literally, as an extravagant claim that individual leaders will never die or grow old; rather, it is a metaphorical affirmation of the same point affirmed by Kant's fourth principle of the true church: the guiding rule (i.e., the insight that only the ultimate is unchangeable, precisely because it is empty of specific content) cannot "decay" but "endures long" (cf. DDJ 21). Lao Zi says this "formless" reality is "unchanging" because it came "into existence before Heaven and Earth" and therefore "may be regarded as the Mother of all things" (DDJ 25). This original Dao, mentioned in Chapter 1, appears again in Chapter 32: "The Tao, considered as unchanging, has no name."

By mastering the incessant interplay of the dark and light forces (i.e., the yin and yang that cause everything in nature to change constantly), the sage relies on "the unchanging excellence" of the Dao as the ultimate source of good governance (DDJ 28). What is the secret of the Dao's unchanging excellence? Chapter 46 tells us "the sufficiency of contentment is an enduring and unchanging sufficiency." This seems to conflict with Kant's emphasis on continually striving to live a better and better life (see §2)-and as we shall consider in $\S 4$, perhaps it really does conflict with any bias toward individual self-perfection. Nevertheless, this does not negate the fact that both Kant and Lao $\mathrm{Zi}$, each in his own unique way, insist we must ultimately rest content in the awareness that, struggle as we may to live the kind of life we believe is befitting for a member of our specific ethical community, with its specific (contingent) beliefs, rituals, and administrative rules, the ultimate rule (i.e., the value of a good will, or the power of the Dao) never changes.

As in the case of the other three principles, Lao Zi's way of implementing this formal principle is not identical to Kant's: what is unchangeable in Daoism is the incessant dynamic flow of nature in accordance with the principles of yin and yang; what is unchangeable for Kant is (ultimately) the architectonic structure of reason, as 
imbedded in his table of categories. ${ }^{29}$ Moreover, Kant looks forward to the church ushering in an ultimate historical reality that he calls "the Kingdom of God on earth"; ${ }^{30}$ Daoism has no direct equivalent, no moral goal for human history-except perhaps a return to the ideal society of old (e.g., $D D J 8$ ). To the question of just how significant such differences would be, for the task of constructing a Kantian church on a Daoist model, we shall now turn our attention.

\section{CONCLUDING REFLECTIONS: KANTIAN STRIVING VS. DAOIST CONTENTMENT}

The passages quoted in $\S 3$ confirm that the Dao-De-Jing can be interpreted as upholding principles that are at least similar, if not identical to the four principles that Kant regards as the essential building-blocks of any "true church". The significant differences we detected in some cases were not differences in the nature of the principle or goal that Lao $\mathrm{Zi}$ and Kant are aiming at, but only in the path or procedure each proposes as the best way of implementing the relevant principle. The question that remains is whether or not a religious community based on Lao $\mathrm{Zi}$ 's account of how to implement these principles would retain enough of what Kant had in mind for it to qualify as (what I have called, in the title of this article) a "Kantian church". I believe it could, especially if we take into consideration the principle of balance between the opposite forces of yin and yang-terms Lao $\mathrm{Zi}$ actually uses only once (DDJ 42), but nevertheless seem to undergird his entire text. Before concluding with an explanation of how such a synthesis is possible, I shall address two potential objections to the entire project of constructing a Daoist-Kantian church.

First, one might object that the writing styles and philosophical assumptions of Lao $\mathrm{Zi}$ and Kant are too different for this project ever to get off the ground. Indeed, Kant's respect for and dependence on rational argumentation and autonomous selfobservation stands in marked contrast to Lao Zi's respect for and dependence on a mystical experience of the way opposites are paradoxically reconciled through a deep trust in nature. Moreover, while Kant explicitly refers to the necessity of intentionally organizing actual churches, in hopes of bringing humanity closer to realizing "the Kingdom of God on earth", ${ }^{31}$ serious doubts could be raised as to whether Lao Zi would give any credence to the claim that an actual, empirical organization could be set up on the basis of his philosophy. He discounts the importance of purposive

\footnotetext{
${ }^{29}$ For a defense of the claim that the table of categories is Kant's primary illustration of how architectonic unity is manifested in his own philosophy, see Palmquist 2011.

${ }^{30}$ That this "on earth" is a crucial focus of Kant's vision of the church is indicated in the very title of the Third Piece: "The Victory of the Good over the Evil Principle and the Founding of a Kingdom of God on Earth"; it comes to the fore toward the end of Division One and in Division Two (Kant 2009, 123-37). For a discussion of the relation between the political and religious aspects of this emphasis, see Palmquist 1994.

${ }^{31}$ See note 30, above. Immediately after arguing that God must be the founder of the true (invisible) church, Kant adds that when it comes to setting up actual churches, "the human being... must...proceed in such a way as if everything depended on him" (Kant 2009, 101). For a discussion of the delicate balance Kant requires, between divine assistance and human responsibility, see Palmquist 2009b.
} 
activity in general, so how could the concept of a historical goal for human organizations (as implied by Kant's theory of the church as the vehicle for realizing the telos of human history) carry any weight?

In reply, let me clarify that I have not argued, and do not believe the textual evidence presented in $\S 3$ implies, that Lao Zi and Kant share a similar approach to doing philosophy, nor that they agree on the practical implications of the (similar) ideals they both affirm. Quite to the contrary, I have pointed out several important differences between them, and I shall highlight what I take to be the key difference, later in this concluding section. On the specific issue of affirming a role for an empirical organization, however, we should note that Kant is not as different from Lao $\mathrm{Zi}$ as he might at first seem to be. For Kant's "affirmation" of the church conceals a critique of traditional Christian religious beliefs and practices that is no less radical than Lao Zi's critique of traditional Confucian morality and religion. Likewise, Kant's hope that the Kingdom of God will eventually establish itself on earth is moderated by a stark realization that this ultimate goal might never be reached in any temporal sense (see note 24, above). As such, Kant's insistence that the goal is an earthly one, not merely the wishful thinking of "pie in the sky when you die", is entirely consistent with Lao Zi's insistence that the Dao manifests itself in the harmony exhibited between heaven and earth.

A second possible objection to my central claim, that Kant's philosophy of religion is compatible with a Daoist worldview, is that Kant himself had a low view of Chinese philosophy and would surely recoil at the thought of such a synthesis. Most discussions of Kant's view of Chinese philosophy examine his view of Confucius and Confucianism, ${ }^{32}$ so they are irrelevant here. But Kant does occasionally refer to the more mystical Chinese traditions, as when he illustrates "the speculative man [who] becomes entangled in mysticism where his reason does not understand itself" (a situation that is not "fitting for an intellectual inhabitant of a sensible world") by describing how "Chinese philosophers strive in dark rooms with eyes closed to experience and contemplate their nihility" (Kant 1963, 335-36). My brief response is simply that Kant was not well versed in Chinese philosophy; had he been presented with textual evidence such as the passages cited above, he may well have been as open to the suggestion of compatibility as he was in the case of the Confucian tradition. But even if Kant still would have shied away from acknowledging the correspondences outlined above, this is irrelevant to my argument, which is not that Kant himself was sympathetic to Daoism, nor that he appreciated the potential for a Daoist application of his religious principles, but only that such an application can be made, and made with a significant degree of plausibility.

With these clarifications in mind, I shall now conclude by recalling the main difference between a "normal" Kantian church (i.e., one modeled on the Christian tradition that Kant explicitly appealed to, in Religion) and the proposed Daoist church,

\footnotetext{
${ }^{32}$ The historical issues of Kant's awareness of the Chinese philosophical tradition and of why Kant sometimes responded to it in an apparently negative way are discussed in several chapters of Palmquist 2010a. See especially Giesen 2010, Nelson 2010, Rieu 2010, and Vos 2010.
} 
based on the same four principles, and ask whether the latter would retain enough likeness to the former to deserve the label "Kantian". The chief difference I have in mind was highlighted near the end of $\S 2$ : Kant repeatedly insists that the outward sign of a person whom we can rightly regard as a "member" of the true church is for such a person to be continually striving for perfection in his/her lifestyle (i.e., in the shaping of one's deeds according to one's heartfelt conviction to be good); Lao Zi, by contrast, repeatedly insists that the outward sign of a person whom we can rightly regard as a "sage" is that such a person must not be purposefully striving for perfect virtue, but must have adopted an unpretentious attitude of easy-going contentment with the way things are. I shall make four observations regarding this crucial difference.

First, Kant's emphasis on striving does not play an essential role in any of the four principles as such; rather, it is informed by his decision to base his second experiment on Christianity. Consider, for example, St. Paul's testimony to the Philippians. After reciting his credentials as a former Pharisee (Phil. 3:4-6), Paul confesses that his own inadequacy (as judged by the Mosaic Law) requires him to appeal to faith in the new path forged by the self-sacrificial sufferings of Jesus that he now tries to imitate (Phil. 7-11). He then adds (3:12-4): "Not that I have already obtained all this, or have already arrived at my goal... But one thing I do: Forgetting what is behind and straining toward what is ahead, I press on toward the goal to win the prize for which God has called me heavenward in Christ Jesus." Kant's moral writings consistently exhibit a similar emphasis on continual striving to sacrifice the desires of the flesh in the quest for virtue. Since this emphasis is rooted in a particular historical faith, it may not be essential to the religion of reason as such (i.e., to the first experiment). The fact that Dao-De-Jing de-emphasizes the striving implicit in purposeful action does not imply that it renders Kant's whole project unworkable. Rather, given the substantial weight of textual support for Kant's four basic principles, we can interpret Lao $\mathrm{Zi}$ as arguing that the best way to reach these very goals is not to try our best to reach them, but to immerse ourselves in nature's way of promoting such goals, by relaxing and trusting the way things are (i.e., the Dao).

Second, Kant's emphasis on radical evil in human nature, and the resulting need for a revolutionary conversion (or "change of heart") to pull us out of this selfdeceptive hole, has no obvious equivalent in Lao Zi. At least, Lao Zi never explicitly appeals to anything that obviously corresponds to Kant's principle of the "propensity to evil" in human nature. However, this difference may not be as significant as it first seems to be. For if we interpret radical evil as our natural human tendency to live in an unnatural way, then the conversion Lao Zi preaches is a return to the natural; and this seems quite compatible with Kant's claim that we must revitalize (what he calls) the "predisposition to good" in human nature (Kant, 2009, 26-8). Significantly, our predisposition is a natural characteristic of being human that includes our animality! Thus, Kant's position (like Lao Zi's) is that we must begin by embracing our embodiment, if we are to overcome the natural tendency to live an inauthentic life. Indeed, the predisposition to "humanity" stands as the harmonizing middle term 
between the heavenly predisposition of "personality" and the earthly predisposition of "animality".

Third, the most obvious difference between Kant and Lao Zi, when it comes to their respective understandings of the four principles of church government, lies in their take on purity. Insofar as Kantian purity is necessarily grounded in a set of rationally-constructed principles that we must consciously employ in order to decide which actions are "ethically good" and which are "ethically evil", Lao Zi's approach seems to take virtually the opposite path. Many examples in Kant's moral writings, as well as virtually all of his Metaphysics of Morals, admittedly give the impression that he viewed moral purity in a way much closer to the Confucian view [just as so many past comparative studies have claimed (see note 32)], than to the Daoist view. But this does not change the fact that both approaches uphold purity as a grounding virtue, and that Kant sometimes affirms a kind of negative purity (i.e., an absolute reliance on an unknown good will) that is similar to Daoist purity. Kant's name for this transcendent form of moral purity is "holiness" (as opposed to "virtue"). The point at issue, then, is not whether purity is a grounding principle for a religious community. On that, Lao $\mathrm{Zi}$ and Kant agree. The point of divergence relates to how we recognize and bring about purity.

Finally, a closer look at Kant's references to striving reveals that what religion bids us to strive after is not individual acts of moral virtue, for these are always only partial and imperfect and will never enable us to reach the goal of becoming perfect. Rather, Kant associates our "striving after that kingdom of heaven", described symbolically in the Bible as "the end of the world" (Kant, 2009, 134), with holiness: "in general holiness shall be the goal toward which a human being ought to strive" (159), just as Jesus claimed in the Sermon on the Mount (Matt. 5:48). Indeed, Kant says Jesus' two great commandments (to love God and neighbor) "are not merely laws of virtue, but precepts of holiness, the holiness which we ought to strive after, but in regard to which the mere striving is called virtue" (161). Here Kant implies that the only way human beings can obtain virtue (since we cannot obtain perfection through individual good deeds) is to strive for holiness. Thus, even though he regards "effects of grace" as essentially incomprehensible, Kant admits that we may need "to have faith that there may be effects of grace, and that perhaps there even have to be such effects to compensate for the imperfection of our striving for virtue" (174). This is precisely why Kant thinks we must be religious: striving for virtue as a goal necessarily fails; paradoxically, only by striving for holiness may we hope to become virtuous. ${ }^{33}$ The question Kant never directly faces is: how is the latter sort of striving

\footnotetext{
${ }^{33}$ As Kant puts it in Kant, 2009, 183: "the doctrine of godliness cannot on its own constitute the final purpose of moral striving but can serve only as a means to strengthen that which in itself constitutes a better human being, the virtuous conviction [Gesinnung], by promising and securing to it (as a striving toward the good, even toward holiness) the expectation of the final purpose of which this conviction is incapable. The concept of virtue, by contrast," awakens within us "an ability ... whereby we can become masters over the greatest obstacles within us, in the dignity of the humanity which the human being must venerate in his own person and in the vocation thereof, and after which he strives in order to attain it ...". In other words, virtue must come first, but one who merely strives to be virtuous will
} 
different, in practical terms, from the former? ${ }^{34}$ Daoism provides an answer that Kant never seems to have considered.

The foregoing analysis suggests that both Kant and Lao $\mathrm{Zi}$ defend a form of negative theology, whereby very little (if anything) positive can be said about God (or the Dao), and what can be said usually leads us into antinomies (or paradoxical claims); but these limitations do not prevent the sincere person from knowing the right way to be, and from practicing that way of being. What this study brings out is that Kant's four principles of church organization are not an exception to, but a crucial part of, this theological foundation for a religious community. That is, the four basic principles function (for both Kant and Lao $\mathrm{Zi}$ ) to prevent those who accept them from allowing individual self-perfection (something that forever lies beyond our grasp) to usurp the place that properly belongs to community perfection. Yet, Lao Zi and Kant share a low view of ritual and other organized religious activities. The ethical "community" that is to become real through the organization of a Kantian church need not be religious in any traditional sense, but must uphold a highly rarefied conviction that what is ultimate makes all forms of religious traditions (all rituals and dogmatic beliefs) virtually irrelevant, aside from the benefit they can give to the community itself. In other words, despite Kant's apparent promotion of a quasiConfucian moral system, his critique of traditional religious organizations is entirely compatible with the Daoist critique of Confucian ritual as a way of actually helping people to become moral.

The basic principle of Chinese philosophy, the balance of opposites, suggests that a combination of the Daoist yin (contented trust in a holiness we can neither control nor understand) with the Kantian yang (striving for virtue by conforming our conduct to the same holiness) would be a more powerful model for organizing a religious community than either approach, taken on its own. The former would add new dimensions to freedom that the latter on its own only alludes to (see $\S 3 \mathrm{c}-\mathrm{d}$ ). From the perspective of Kant's first experiment, no objection can be raised to such a synthesis, provided (as we have seen) both sides agree that the principles being upheld are universality, purity, freedom, and unchangeableness. While the foregoing arguments do not constitute a full-blown account of how such a synthesis would actually work in practice, they do demonstrate the possibility of a Daoist model for a Kantian form of religious life. While it might not look very similar to either the traditional Christianity that Kant was familiar with (and responding to) or traditional Daoist religious practices (even those that incorporate Lao Zi's ideals), such a Daoist-Kantian church should surpass both approaches in its ability to accomplish the central principles

inevitably fail; we cannot reach the goal of virtue unless we reinterpret it in religious terms, as a striving for holiness.

${ }^{34}$ The closest Kant comes is to say what such striving is not: "wanting to bring [justification] about by striving for a supposed interaction with God" is a superstitious "delusion" (Kant, 2009, 174). Whatever "being holy" means for Kant, it cannot be detached from a person's duty "to be a good human being" (174). To strive to please God without defining this in terms of what is already our own moral duty (i.e., "the striving for the good way of life" [178]) is the essence of what Kant calls "pseudoservice" of God (cf. 176-7 and 178-9). 
upheld by them all. Attempting such a synthesis should bring us one step closer to realizing the virtues of both the contentment promised by Daoist sagacity and the striving required by Kantian virtue.

\section{ACKNOWLEDGEMENTS}

Earlier versions of this paper were presented at a conference on "Religion and Philosophy in Germany and China," held at Free University of Berlin in July 2010, at a "Symposium on Daoism and Contemporary Philosophy," held at San Jose State University in April 2011, and as a public lecture held at Oklahoma State University in September 2012. I benefited from valuable feedback given by participants at each of these events, as well as from Ellen Zhang and Andrej Fech. I am especially grateful for the many detailed suggestions and observations raised by three anonymous referees, prompting most of the footnotes now included in $\S 3$. Thanks also for travel funding provided by the sponsors of the first and third events mentioned above and by the Arts Faculty at HKBU (for the second event), and for research funding provided by the Research Grants Council of Hong Kong.

\section{REFERENCES}

Boaz, David (1997), Libertarianism-A Primer (New York: Free Press).

Giesen, Klaus-Gerd (2010), “Asian Hospitality in Kant's Cosmopolitan Law”, in Palmquist 2010a, 753-63.

Green, Ronald (1978), Religious Reason: The Rational and Moral Basis of Religious Belief (New York: Oxford University Press).

Kant, Immanuel, Religion within the Bounds of Bare Reason, trans. Werner S. Pluhar (Indianapolis: Hackett). Also abbreviated Religion; references cite the pagination found in volume 6 of the Berlin Academy Edition of Kant's works.

---- (1963), trans. Robert E. Anchor as The End of All Things, in L.W. Beck (ed.), Kant on History (New York: Bobbs-Merrill), 69-84. References cite the pagination found in volume 8 of the Berlin Academy Edition of Kant's works.

Lao Zi, Dao-De-Jing, trans. James Legge (1891), in Sacred Books of the East, online at http://www.religionfacts.com/taoism/tao_te_ching.htm. Abbreviated DDJ.

----DDJ, trans. Chan, W.T. (1963), in The Way of Lao Tzu: Tao-Te Ching (Indianapolis: Bobbs-Merrill).

---- DDJ, trans. Hansen, Chad (2004), in Tao Te Ching, online at http://terebess.hu/english/tao/hansen.html.

---- DDJ, trans. Ivanhoe, Philip J. (2001), in The Doadejing of Laozi (Indianapolis: Hackett).

---- DDJ, trans. Lau, D.C. (1963), in Tao Te Ching (Baltimore: Penguin Books). 
---- DDJ, trans. Lynn, Richard John (1999), in The Classic of the Way and Virtue: A New Translation of the Tao-te Ching of Laozi as Interpreted by WangBi (New York: Columbia University Press).

---- DDJ, trans. Mair, V.H. (1990), in Tao Te Ching: The Classic Book of Integrity and the Way (New York: Bantam).

----DDJ, trans. Roberts, Moss (2001), in Dao-De-Jing: The Book of the Way (Berkeley: University of California Press).

Love, Brandon (2010), "Kant's Religious Perspective on the Human Person", in Palmquist 2010a, 563-72.

Mueller, Hans-Georg (2009), The Moral Fool: A Case for Amorality (New York: Columbia University Press).

Nelson, Eric S. (2011), "Kant and China: Aesthetics, Race and Nature", Journal of Chinese Philosophy, 38: 509-25.

---- (2010), "China, Nature, and the Sublime in Kant," in Palmquist 2010a, 333-346.

Palmquist, Stephen R. (2013), "The Idea of Immortality as an Imaginative Projection of an Indefinite Moral Future", in Stefano Bacin, Alfredo Ferrarin, Claudio La Rocca, and Margit Ruffing (eds), Proceedings of the XI. Internationalen KantKongress 2010, Pisa; 22. - 26. Mai 2010 (Berlin: Walter de Gruyter), vol. 2, 91929.

---- (2011), "Architectonic Reasoning and Interpretation in Kant and Yijing", Journal of Chinese Philosophy, 38: 569-83.

----(ed.) (2010a), Cultivating Personhood: Kant and Asian Philosophy (Berlin: Walter de Gruyter).

---- (2010b), "Kant's Ethics of Grace: Perspectival Solutions to the Moral Problems with Divine Assistance", The Journal of Religion, 90: 530-53.

---- (2009a), "Introduction", in Kant 2009, xv-xlix.

----(2009b), "Kant's Religious Argument for the Existence of God-The Ultimate Dependence of Human Destiny on Divine Assistance", Faith and Philosophy, 26: $3-22$.

---- (2008), "Kant's Quasi-Transcendental Argument for a Necessary and Universal Evil Propensity in Human Nature", The Southern Journal of Philosophy, 46: 26197.

----(2000), Kant's Critical Religion: Volume Two of Kant's System of Perspectives (Aldershot: Ashgate).

----(1994), "“The Kingdom of God is at Hand!' (Did Kant really say that?)", History of Philosophy Quarterly, 11: 421-37.

----(1993), Biblical Theocracy: A Vision of the Biblical Foundations for a Christian Political Philosophy (Hong Kong: Philopsychy Press).

Rieu, Alain-Marc (2010), "The Kantian Model: Confucianism and the Modern Divide", in Palmquist 2010a, 741-52.

Slingerland, Edward (2003), Effortless Action: Wu-wei as Conceptual Metaphor and Spiritual Ideal in Early China (New York: Oxford University Press).

Vos, Rein (2010), "Doing Good or Right? Kant's Critique on Confucius", in Palmquist 2010a, 764-76. 
Wohlfart, Günter (2010), "Metacritique of Practical Reason", in Palmquist 2010a, 5373. 